\title{
Climatic evolution across oceanic anoxic event 1a derived from terrestrial palynology and clay minerals (Maestrat Basin, Spain)
}

\author{
JEAN CORS*, ULRICH HEIMHOFER* ${ }^{*}$, THIERRY ADATTE $\ddagger$ PETER A. HOCHULI \\ STEFAN HUCK* \& TELM BOVER-ARNAL \\ *Institute of Geology, Leibniz University Hannover, Callinstraße 30, 30167 Hannover, Germany \\ †Institute of Geology and Palaeontology, Université de Lausanne, CH-1015 Lausanne, Switzerland \\ §Palaeontological Institute and Museum, University of Zurich, Karl Schmid-Str. 4, Ch-8006 Zurich, Switzerland \\ qDepartament de Geoquímica, Petrologia i Prospecció Geòlogica, Facultat de Geologia, Universitat de Barcelona, c/ de \\ Martí i Franquès s/n, 08028 Barcelona, Spain
}

(Received 29 November 2013; accepted 10 September 2014; first published online 30 October 2014)

\begin{abstract}
Studies dealing with the response of the continental biosphere to the environmental perturbations associated with Cretaceous oceanic anoxic events (OAEs) are comparatively rare. Here, a quantitative spore-pollen record combined with clay mineral data is presented, which covers the entire early Aptian OAE 1a interval (Forcall Formation, Maestrat basin, east Spain). The well-expressed OAE 1a carbon-isotope anomaly is paralleled by changes in the clay mineral assemblage and by a stepwise decline in the normalized frequency of Classopollis pollen (produced by xerophytic Cheirolepidiaceae) with lowest contents occurring during the positive $\delta^{13} \mathrm{C}$ shift. In contrast, Araucariacites and Inaperturopollenites pollen show a pronounced increase in relative abundance from low background values to become a significant component of the palynological assemblage during the Classopollis minimum. The observed changes in clay minerals and pollen distribution patterns are interpreted to reflect a major change in the composition of the hinterland vegetation of the Maestrat Basin, most probably due to short-lived but pronounced climatic cooling and changes in humidity. Temperature anomalies driven by organic carbon burial and associated $\mathrm{CO}_{2}$ decline have been postulated for all major Mesozoic OAEs. The palynomorph record from the Iberian Maestrat basins indicates that the climax of this cooling episode was significantly delayed in comparison to the end of organic carbon-rich deposition in the world oceans.
\end{abstract}

Keywords: early Aptian, Maestrat Basin, oceanic anoxic event 1a, palynology, clay minerals.

\section{Introduction}

Cretaceous oceanic anoxic events (OAEs) have received considerable attention during the last couple of decades and a wealth of information has been obtained on the age and duration, palaeoceanography, biogeochemistry and trigger mechanisms of these episodes (e.g. Jenkyns, 2010). The so-called OAE 1a (locally known as Livello Selli, Niveau Goguel, Fischschiefer) took place during early Aptian time (126.3123.0 Ma; Gradstein et al. 2012) and spanned an interval of approximately 1.0-1.3 Ma (Li et al. 2008) or $1.11 \pm 0.11 \mathrm{Ma}$ (Malinverno, Erba \& Herbert, 2010). In pelagic and hemipelagic settings, OAE 1a is typically expressed as a stratigraphic sequence of finely laminated, organic carbon-rich deposits formed under anoxic (Quijano et al. 2012) or even euxinic conditions (Pancost et al. 2004). In the neritic realm, the time-equivalent deposits are characterized either by a phase of non-deposition or erosion (Wissler, Funk \& Weissert, 2003; Föllmi et al. 2006) or by the growth of a micro-encrusting microbial and/or algal community (Immenhauser, Hillgärtner \& Van Betum, 2005; Bover-

†Author for correspondence: heimhofer@geowi.uni-hannover.de
Arnal et al. 2011; Huck, Heimhofer \& Immenhauser, 2012). The carbon isotope pattern across the OAE 1a is characterized by a rapid, negative $\delta^{13} \mathrm{C}$ excursion followed by a long-lasting positive shift and provides a valuable geochemical signature for high-resolution correlation of marine strata (Menegatti et al. 1998; Herrle et al. 2004; Robinson et al. 2008; Millán et al. 2009; Vahrenkamp, 2010; Moreno-Bedmar et al. 2012; Gaona-Narvaez, Maurrasse \& Moreno-Bedmar, 2013; Yamamoto et al. 2013).

The widespread accumulation of high amounts of sedimentary organic matter (OM) during this event has been linked to peculiar oceanographic and climatic conditions. Whereas the OAE 1a itself has been proposed to reflect an episode of exceptional warmth triggered by volcanic activity (Larson \& Erba, 1999; Méhay et al. 2009; Bottini et al. 2012), enhanced organic carbon sequestration in marine sediments has been interpreted to result in $\mathrm{CO}_{2}$ drawdown and subsequent cooling (Hochuli et al. 1999; Bellanca et al. 2002; Ando et al. 2008; Jenkyns, 2010). Episodes of exceptional climatic warmth (haline euxinic acidic thermal transgression or HEATT episodes of Kidder \& Worsley, 2010) are expected to have had a pronounced effect on the association and distribution of terrestrial vegetation. 
Prominent changes in floral compositions associated with major carbon-cycle perturbations have been reported for the Palaeocene-Eocene thermal maximum (Wing et al. 2005; Jaramillo et al. 2010), the TriassicJurassic transition (McElwain, Beerling \& Woodward, 1999; Bonis, Kürschner \& Krystyn, 2009; van de Schootbrugge et al. 2009) and the Permian-Triassic warming event (Looy et al. 1999; Hochuli et al. 2010; Hermann et al. 2011). Given the proposed climatic impact of Cretaceous OAEs on the entire oceanatmosphere system, a better understanding of the response of continental vegetation composition and dynamics is highly relevant. The high sea-surface temperatures (SSTs) proposed for tropical and subtropical sites for the early Aptian OAE 1a (Schouten et al. 2003; Dumitrescu et al. 2006; Ando et al. 2008) would imply even higher (surface air) temperatures for continental settings during this event. Temperature extremes during late Early Cretaceous time may have exceeded the heat tolerance of low-latitude terrestrial ecosystems at times, resulting in the apparent sparseness of land plant vegetation in the tropical-equatorial hot arid belt (Chumakov et al. 1995; Hay \& Floegel, 2012).

In contrast to the marine record of the OAE $1 \mathrm{a}$, information on the response of terrestrial ecosystems to this exceptional event is relatively scarce. This is mainly due to the lack of suitable and well-dated continental archives covering the early Aptian time span. In marine settings, the overwhelming occurrence of algal and/or bacterial-derived amorphous OM within the black shale horizons often hampers accurate palynological analysis and a quantitative assessment of spore-pollen assemblages. In addition, due to their distance to the coast, pelagic deposits often contain only a small portion of continent-derived spores and pollen, with the assemblages being potentially biased due to long transport distances (Heusser \& Balsam, 1977; Tyson, 1995; Traverse, 2007). Only a few records exist at this stage, which are essentially based on spore-pollen data from stratigraphically wellconstrained marine sections located along the northern margin of the western Tethys (Hochuli et al. 1999; Heimhofer et al. 2004, 2006; Keller et al. 2011; Najarro et al. 2011). Whereas most of the latter studies focus essentially on the OAE 1a interval itself and on pre-OAE strata, only Hochuli et al. (1999) provide a palynological record covering the entire event and its aftermath.

In this study, we present a spore-pollen record covering the entire early Aptian OAE 1a interval and its aftermath. Palynofacies analysis provides information on sea-level changes and any potential bias of the spore-pollen dataset due to hydrodynamic sorting. The studied succession deposited in the Maestrat Basin of eastern Spain is bio- and chemostratigraphically well constrained, which allows a comparison of changes in the palynoflora with existing sporepollen records across OAE 1a, as well as with palaeoclimatic proxy data from the continental and marine realms.

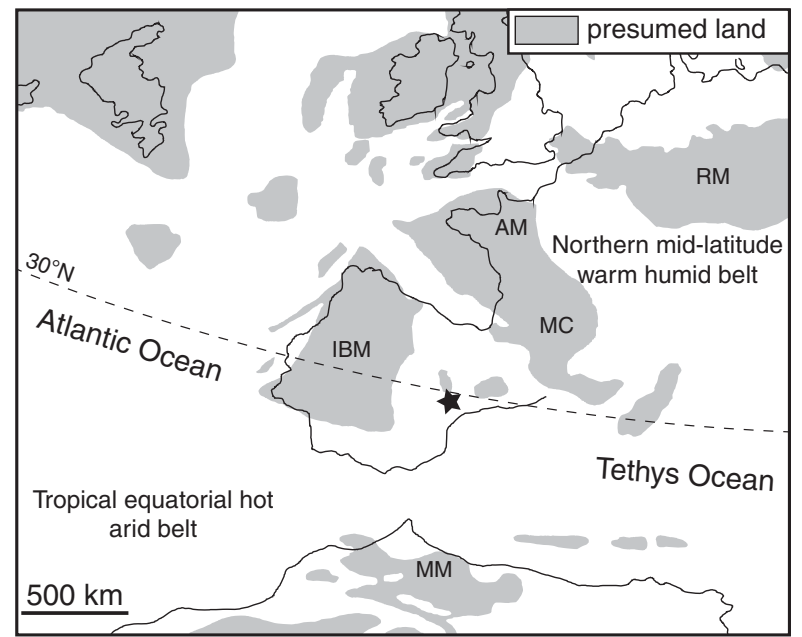

Figure 1. Palaeogeographic reconstruction of the western Tethys region during late Early Cretaceous time (modified after Ziegler, 1990). Distribution of major climate belts after Chumakov et al. (1995). Study site is marked with an asterisk. AM - Armorica Massif; IBM - Iberian Massif; MC - Massif Central; MM Morocco Meseta; RM - Rhenish Massif.

\section{Geological setting}

Lower Cretaceous marine and continental sediments are well exposed in the Galve sub-basin of the Maestrat Basin in the eastern Iberian Chain of Spain. During Late Jurassic and Early Cretaceous times, extension of the Iberian plate due to the opening of the Central and North Atlantic domains resulted in rifting and in the formation of several intraplate basins, including the Maestrat Basin and its sub-basins (Fig. 1; Salas et al. 2001). Here, deposition of terrigenous siliciclastics and epeiric carbonates took place under differential subsidence in a complex tectonic setting, resulting in extraordinary sedimentary thicknesses (BoverArnal et al. 2010). Tectonic inversion during the Alpine Orogeny caused faulting, uplift and the formation of the Iberian Chain (Salas et al. 2001).

The studied Barranco de las Calzadas (BdlC) section is located in the province of Teruel, about $5 \mathrm{~km} \mathrm{NE}$ of the village Villarroya de los Pinares. The succession is accessible in outcrop on the eastern limb of the NNWSSE-striking Miravete anticline. Here, about $450 \mathrm{~m}$ of early Aptian (Bedoulian) deposits are subdivided into the Morella, Xert, Forcall and Villarroya de los Pinares formations (Canérot et al. 1982). The investigated section covers $150 \mathrm{~m}$ of the Forcall Formation and is essentially composed of epeiric marine marls with intercalations of orbitolinid-rich, nodular and sand-rich limestone beds. The succession represents part of a large-scale transgressive-regressive sequence (BoverArnal et al. 2010; Embry et al. 2010). In the lower part of the Forcall Formation (305-311 m), a conspicuous carbonate horizon composed of coral rubble encrusted by Lithocodium aggregatum is noteworthy (BoverArnal et al. 2011).

The stratigraphic assignment of the lower Aptian succession in the eastern Iberian Chain is well 
constrained based on magnetostratigraphy (Salas et al. 2005), carbon isotope stratigraphy based on bulk carbonate (Bover-Arnal et al. 2010; Embry et al. 2010) and ammonite biostratigraphy (Moreno-Bedmar et al. 2009, 2010). The Forcall Formation is dated by ammonites as early Aptian (Bedoulian) and comprises the complete Deshayesites forbesi and Deshayesites deshayesi zones and the lower part of the Dufrenoyia furcata biozone (Moreno-Bedmar et al. 2010). Additional stratigraphic refinement is obtained from carbon isotope data, which show a characteristic early Aptian trend with stratigraphic height (Moreno-Bedmar et al. 2009; Bover-Arnal et al. 2010;). However, despite the excellent match of the existing carbon isotope curve with published reference records (Menegatti et al. 1998; Gaona-Narvaez, Maurrasse \& Moreno-Bedmar, 2013), the stratigraphic significance of the abrupt negative shift (C3) in the record of Bover-Arnal et al. (2010) remains questionable. Given the distinct lithological changes associated with this short-lived negative shift, a diagenetic bias of the signature cannot be ruled out.

\section{Palaeogeography and palaeophytogeography}

During late Early Cretaceous time, the progressive fragmentation of Laurasia in combination with high sea level resulted in the formation of an archipelago composed of isolated emergent landmasses along the northwest margin of the Alpine Tethys Ocean (Hay et al. 1999). The Iberian Massif was situated at the southwest tip of this archipelago at an approximate palaeolatitude of $30-35^{\circ} \mathrm{N}$ (Sewall et al. 2007). During Aptian time, the Iberian Massif formed an isolated, low-relief island surrounded by intracratonic basins (including the Maestrat Basin) covered by shallow epeiric seas. Towards the southeast, these epicontinental seas passed into the deep oceanic realm of the Alpine Tethys Ocean. The Iberian landmass was probably the main source for all types of erosional products as well as for land plant-derived debris and sporomorphs deposited in the Maestrat Basin.

Climatic conditions during Aptian time were characterized by global warmth as indicated by low meridional thermal gradients, reduced seasonality, high atmospheric $\mathrm{CO}_{2}$ levels and the absence of large continental ice sheets (Huber, Hodell \& Hamilton, 1995; Price, 1999; Herman \& Spicer, 2010; Jenkyns et al. 2012). The Iberian Massif was situated in a transitional position between two major climatic zones: the tropical-equatorial hot arid belt in the south and the mid-latitude warm humid belt in the north (Chumakov et al. 1995; Skelton et al. 2003). This resulted in a subtropical, seasonally dry (semi-arid to arid) climate in most parts of Iberia during late Early Cretaceous time (Ruffell \& Batten, 1990; Heimhofer et al. 2008; Diéguez, Peyrot \& Barrón, 2010). Consequently, the vegetation of this winterwet biome was dominated by xerophytic forests composed of microphyllous conifers and diverse fern communities forming the understory.
Additional floral elements are seed ferns, ginkgoales, horsetails, lycopsids and, of subordinate importance, early representatives of the angiosperms (Solé de Porta et al. 1994; Diéguez, Peyrot \& Barrón, 2010; Friis, Pedersen \& Crane, 2010).

\section{Materials and methods}

A total of 50 samples were collected at regular levels throughout the BdlC section, Maestrat Basin, eastern Spain, resulting in a sample spacing of $2.5 \mathrm{~m}$. In order to minimize contamination by modern plant debris and/or near-surface weathering processes, the uppermost $15-20 \mathrm{~cm}$ of sediment were removed before sampling. Following collection, the sample material was dried at $40^{\circ} \mathrm{C}$ in a laboratory oven before further processing.

\section{4.a. Carbon and oxygen isotopes}

Measurement of stable carbon and oxygen isotopes of sedimentary carbonates was carried out on powdered bulk sample material (c. $0.5 \mathrm{mg}$ ) on a total of 50 samples. An additional 18 samples were taken from a hand-specimen collected from a Lithocodium-rich limestone unit (305-311 m) in order to investigate the significance of the negative shift, which marks the onset of the OAE 1a. Stable isotope analysis was conducted using a Thermo Fisher Scientific Gasbench II carbonate device connected to a Thermo Fisher Scientific Delta 5 Advantage isotope ratio mass spectrometer, available at the Leibniz University, Hannover, Germany. The gas bench uses viscous water-free $\left(98 \mathrm{~g} \mathrm{~mol}^{-1}\right)$ orthophosphoric acid at $72{ }^{\circ} \mathrm{C}$ to release $\mathrm{CO}_{2}$ of the calcite from the sample material $1 \mathrm{~h}$ before the start of the measurement. Repeated analyses of certified carbonate standards (CO-1, NBS-18, NBS-19) show an external reproducibility $\pm 0.1 \%$ for $\delta^{18} \mathrm{O}$ and $\pm 0.08 \%$ for $\delta^{13} \mathrm{C}_{\text {carb }}$. Values are expressed in conventional delta notation relative to the Vienna-Pee Dee Formation belemnite (VPDB) international standard, in parts per mil (\%). A total of nine duplicate measurements shows that the measured values are representative and indicate that the samples are quite homogenous (maximum deviation for duplicate measurements is \pm 0.2 for $\delta^{18} \mathrm{O}$ and \pm 0.08 for $\delta^{13} \mathrm{C}$ ).

\section{4.b. Clay minerals}

A total of 37 samples from the BdlC section were analysed for their clay mineralogy. Clay mineral analyses were based on methods described by Kübler (1987). Ground chips were mixed with deionized water $(\mathrm{pH} 7-$ 8 ) and agitated. The carbonate fraction was removed by addition of $10 \% \mathrm{HCl}$ at room temperature for $20 \mathrm{~min}$ or longer until all the carbonate was dissolved. Ultrasonic disaggregation was accomplished during $3 \mathrm{~min}$ intervals. The insoluble residue was washed and centrifuged (5-6 times) until a neutral suspension was obtained ( $\mathrm{pH} 7-8)$. Separation of two different grain size 
fractions $(<2 \mu \mathrm{m}$ and $2-16 \mu \mathrm{m})$ was obtained by the timed settling method based on Stokes' law. The selected fraction was then pipetted onto a glass plate and air dried at room temperature. X-ray diffraction (XRD) analysis of oriented clay samples were carried out after air drying at room temperature and under ethyleneglycol solvated conditions. The intensities of selected XRD peaks characterizing each clay mineral present in the size fraction (e.g. chlorite, mica, kaolinite and illite-smectite mixed layers) were measured for a semiquantitative estimate of the proportion of clay minerals present in two size fractions $(<2 \mu \mathrm{m}$ and $2-16 \mu \mathrm{m})$. Determination of the illite-smectite mixed layers and their content in smectitic expandable layers is based on the method of Moore \& Reynolds (1997).

\section{4.c. Palynology}

A total of 38 rock samples from the BdlC section were prepared for palynological analysis by the Geological Survey of North Rhine-Westphalia in Krefeld, Germany. Cleaned, crushed and weighed samples (20$50 \mathrm{~g}$ ) were treated with $\mathrm{HCl}$ and $\mathrm{HF}$ following standard palynological preparation techniques (e.g. Traverse, 2007). All 38 productive samples were studied for their particle content (palynofacies) and sporomorph assemblage (spores and pollen). For analysis of the palynofacies, a minimum of 300 particles was counted from strew mounts. For the spore-pollen assemblage, a minimum of 200 grains were determined per slide. Variations in the spore-pollen assemblage represent normalized frequencies and are reported as a percentage $(\%)$ of the total assemblage. Light photomicrographs were taken using an Olympus BX 53F light microscope (LM) equipped with an integrated 5 megapixel Olympus XC50 digital camera. The preservation of the studied palynomorphs varies from moderate to very good. Thermally unaltered preservation of organic matter is indicated by the virtually unchanged colouring of the palynomorphs and shows a thermal alteration index (TAI) $<2$ according to Staplin (1982).

\section{Results}

\section{5.a. Stable isotope geochemistry}

Carbon isotope values vary between $-0.3 \%$ and $+5.5 \%$ and show a distinct negative-positive trend with stratigraphic height (Fig. 2). The lowermost part of the section is characterized by $\delta^{13} \mathrm{C}$ values ranging between $+0.2 \%$ and $+1.0 \%$ ( $277-285 \mathrm{~m}$; segment $\mathrm{C} 2$ ). This interval is followed by a gradual negative shift to minimum values of $-0.3 \%$ o (285-296 m; segment $\mathrm{C} 3$ ) and a subsequent positive trend reaching $+2.6 \%$ o (296-312 m; segment C4). For the following $10 \mathrm{~m}$ of section, values remain comparatively stable varying between $+2.6 \%$ and $+3.6 \%$ (312-322 m; segment C5), followed by an additional small-step increase (322-325 m; segment C6). The overlying stratigraphic interval (325-389 m; segment C7) is charac- terized by an increase in $\delta^{13} \mathrm{C}$ up to peak values of $+5.5 \%$. The remaining part of the succession shows a gradual trend towards less positive $\delta^{13} \mathrm{C}$ values. The general pattern of the carbon isotope record matches well with the curve published previously by BoverArnal et al. (2010) for the same section. Integration of the new carbon isotope data with the existing $\delta^{13} \mathrm{C}$ dataset results in an improved high-resolution record for the BdlC section. The new measurements confirm the general stratigraphic trend of the existing $\delta^{13} \mathrm{C}$ record and its principal chemostratigraphic interpretation (Moreno-Bedmar et al. 2009; Bover-Arnal et al. 2010).

\section{5.b. Palynofacies}

In the studied samples, the particulate organic matter is dominated by terrestrial phytoclasts (average $56.9 \%$ ), which account for $14.2-84.1 \%$. Both opaque and translucent phytoclast particles occur in roughly equal abundances. Plant-derived gymnosperm pollen (with angiosperm pollen being of only subordinate importance) vary between 3.5 and $31.3 \%$ (average $12.5 \%$ ), spores are less abundant and reach only 0.3 $5.5 \%$ (average $2.3 \%$ ). Particles of marine origin are dominated by dinoflagellate cysts in the range 1.9 $62.8 \%$ (average $13.5 \%$ ). Acritarchs and foraminifera test linings account for only a small fraction. Amorphous organic matter is composed of orange-brown to grey flakes and represents a consistent fraction of the particulate organic matter (average $6.2 \%$ ).

Based on the quantitative palynofacies analysis, two parameters are used to provide information on the stratigraphic evolution of particulate organic matter sedimentation in the BdlC section. The ratio of continent-derived to marine-derived particles $(\log$ CONT/MAR) is a proxy for distinguishing transgressive-regressive trends (Steffen \& Gorin, 1993; Pellaton \& Gorin, 2005). In addition, the relative abundance of dinoflagellate cysts is used as an indication for increasing marine influence (Tyson, 1995; Pellaton \& Gorin, 2005). The CONT/MAR ratio shows a distinct decrease versus stratigraphic height with a strong dominance of terrestrial particles (CONT/MAR ratio up to 1.7) in the lowermost part of the succession (277-285 m; Figs 2, 3a). The middle part (285$360 \mathrm{~m}$ ) displays lower CONT/MAR ratios of $0.5-1.3$, whereas the uppermost marl-rich part of the section $(360-402 \mathrm{~m})$ is characterized by a decrease towards low ratios ranging between 0.5 and -0.5 . As expected, the relative percentage of dinoflagellate cysts shows an opposing pattern with low abundances (1.9-14.1\%; average $8.0 \%$ ) in the lower and middle part of the section. The upper part (360-402 $\mathrm{m})$ is characterized by a strong increase in dinoflagellate cyst abundance (average $32.1 \%$ ) reaching peak values of $62.8 \%$ at $382 \mathrm{~m}$ (Figs 2, 3b). All palynofacies data are available in the form of online Supplementary Material at http://journals.cambridge.org/geo. 


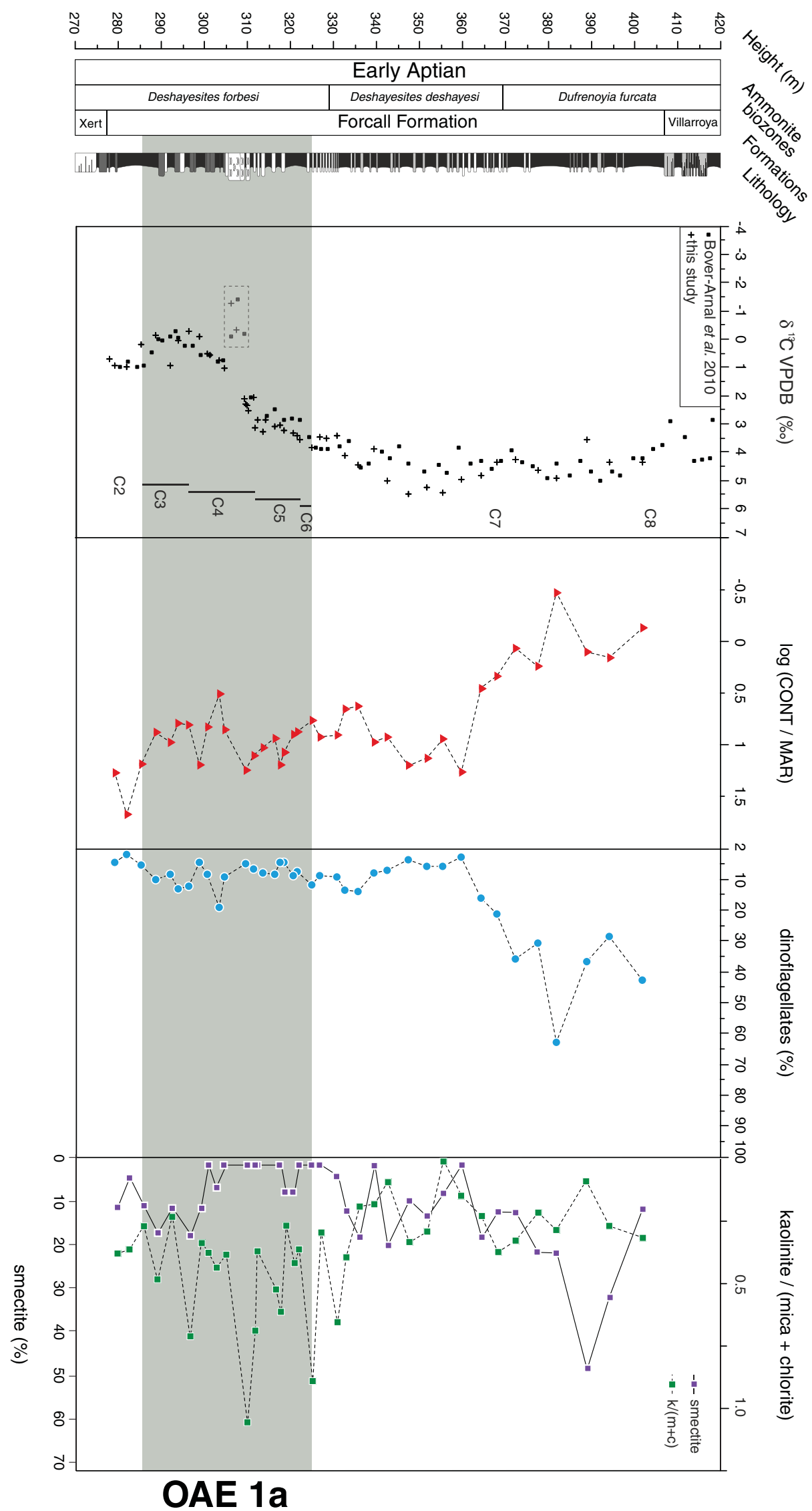

Figure 2. (Colour online) Carbon isotope curve based on bulk carbonate, log CONT/MAR ratio, dinoflagellate cyst abundance, smectite content and kaolinite/(mica + chlorite) ratio plotted against a lithostratigraphic log and biostratigraphic information of the BdlC section, Maestrat Basin, eastern Spain. Litho- and biostratigraphy after Moreno-Bedmar et al. (2009). Carbon isotope data represent a composite curve based on Bover-Arnal et al. (2010) and this study. Negative carbon isotope values framed by stippled line represent measurements from the Lithocodium-rich limestone unit and are excluded from chemostratigraphic interpretation. 


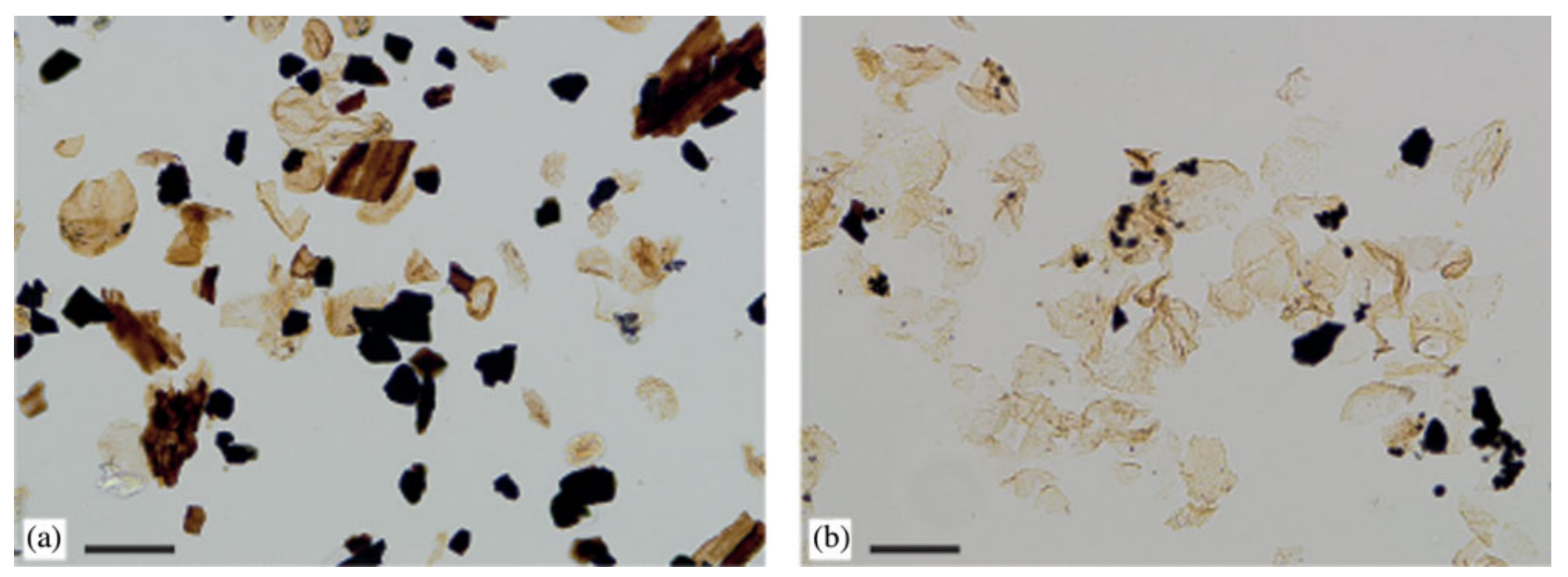

Figure 3. (Colour online) Photomicrographs of two selected palynofacies samples illustrating changes in particulate organic matter composition. (a) Sample MA-4 $(285.0 \mathrm{~m})$ showing a composition strongly dominated by translucent and opaque phytoclasts resulting in a CONT/MAR ratio of 15.5. (b) Sample CA-21 (381.7 m) displaying high abundances of intact and broken dinoflagellate cysts with a CONT/MAR ratio of 0.3 . Scale bar is $50 \mu \mathrm{m}$.

\section{5.c. Clay mineralogy}

In the BdlC section, clay mineral assemblages are mostly composed of smectite, kaolinite, mica (illite) with minor chlorite and illite-smectite mixed layer (IS) components (Fig. 2). The lowest part of the section (C2) is dominated by mica (60-70\%) and kaolinite (20-25\%) with lower abundances of chlorite (5-7\%); smectite and illite-smectite mixed layers (IS) range between 2 and $12 \%$. The $\mathrm{C} 3$ interval is characterized by increased smectite (up to $25 \%$ ) and IS contents to the detriment of mica and, to a lesser extent, kaolinite and chlorite. From C4 upwards, a notable decrease in smectite coincides with higher chlorite contents reaching up to $15 \%$ in the upper part of $\mathrm{C} 4$. Kaolinite and chlorite show an increase in the $\mathrm{C} 5$ and $\mathrm{C} 6$ intervals (up to $40 \%$ and $25 \%$, respectively), while smectite is rarely present within this interval. The lower part of C7 interval is dominated by mica (50-70\%) and shows a distinct decrease in kaolinite, which reaches minimum values (0-20\%), whereas smectite remains low with fluctuating contents of $<25 \%$. The upper part of $\mathrm{C} 7$ is marked by a gradual increase in smectite (up to $50 \%$ ) paralleled by a decline in mica, whereas kaolinite and IS remain low and constant (5-25\%). The overall evolution of the clay mineral assemblage is well expressed in the kaolinite to mica plus chlorite ratio $(\mathrm{K} /(\mathrm{M}+\mathrm{C}))$. All clay mineral data are available in the form of online Supplementary Material at http://journals.cambridge.org/geo.

\section{5.d. Palynology}

The sedimentary deposits of the BdlC section contain a rich and diverse terrestrial palynoflora composed of bisaccate and non-saccate gymnosperm pollen, pteridophyte spores and very few angiosperm pollen. Most spores and pollen were determined on the generic level. In the studied record, 17 genera of gymnosperm pollen (including 3 species), 17 genera of spores and two types of angiosperm pollen can be differentiated (Fig. 4). The assemblage is strongly dominated by non-saccate conifer pollen, which account for $88.6 \%$ of the total assemblage on average. Bisaccate pollen grains (including conifer-derived Alisporites spp., Parvisaccites spp. and Podocarpidites spp. as well as the pteridosperm pollen Vitreisporites pallidus) account for less than $2.0 \%$ and show only minor variations with stratigraphic height. Despite a relatively high diversity, spores produced by bryophytes (Stereisporites spp.), lycopsids (Leptolepidites spp., Retitriletes spp.) and ferns make up less than $9.0 \%$ on average. Among the fern spores, the most abundant taxa include Cicatricosisporites spp. (average $2.8 \%$ ), Cyathidites spp. (average 1.0\%) and Deltoidospora spp. (average $0.8 \%$ ). The low and stable total spore content is well reflected in a high and constant pollen-spore ratio, which characterizes the entire succession (Fig. 4). The assemblage of non-saccate conifer pollen is dominated by Classopollis pollen, accounting for an overwhelming $63.6 \%$ on average. Other quantitatively important forms produced by conifers include Inaperturopollenites spp. (up to $31.6 \%$; average $11.6 \%$ ), Araucariacites spp (up to $20.1 \%$; average $6.5 \%$ ) and Callialasporites spp (including $C$. damperi and $C$. trilobatus; up to $5.7 \%$; average $2.4 \%$ ). Additional gymnosperm pollen of bennettitalean affinity such as Exesipollenites spp. (up to $4.7 \%$ ) or ginkoalean/cycadalean affinity such as Cycadopites spp. (up to $6.0 \%$ ) are only of subordinate importance (average $1.2 \%$ and $1.5 \%$, respectively). Similarly, pollen produced by gnetalean plants (Ephedripites spp, Steevesipollenites spp.) account for less than $0.5 \%$ of the total sporomorph assemblage.

Together, the three conifer pollen taxa Classopollis spp., Inaperturopollenites spp. and Araucariacites spp. make up $61.1-96.6 \%$ of the total sporomorph assemblage. Interestingly, these three groups show significant variations in normalized frequency distribution with stratigraphic height. In the lowermost part of the succession (278.8-303.0 m), Classopollis 


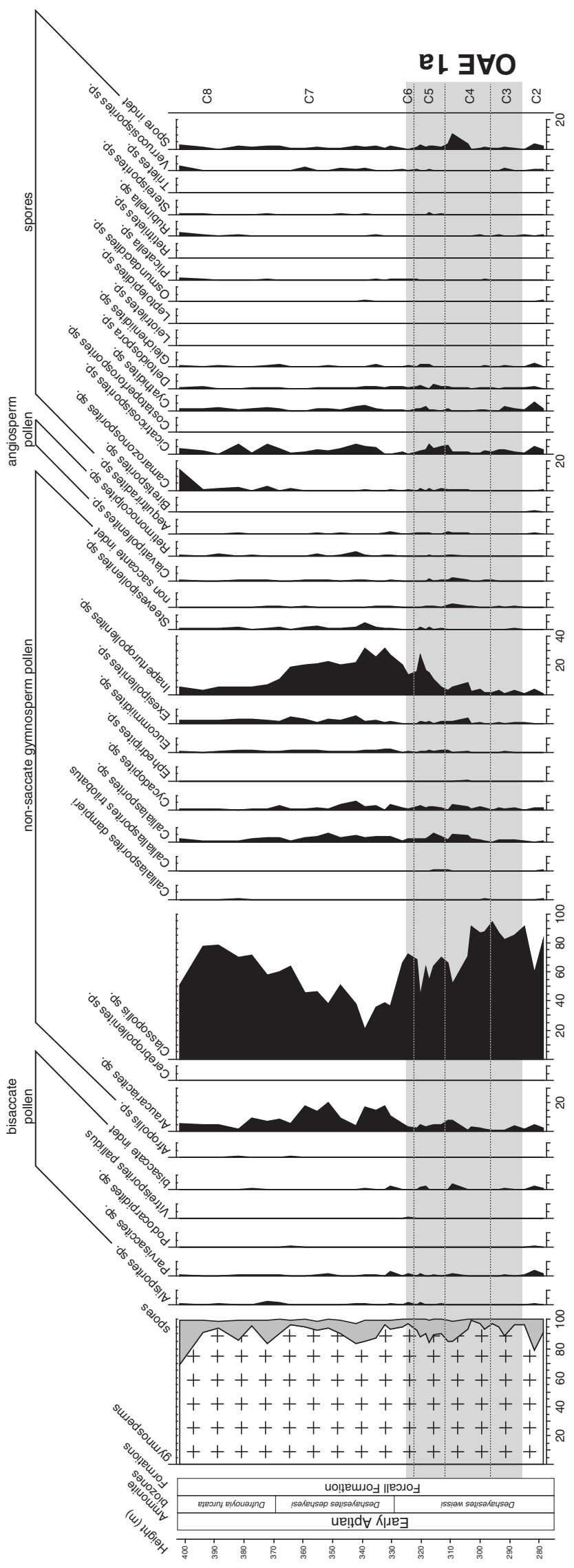

Figure 4. Relative abundances (\%) of spores and pollen in the BdlC section, Maestrat Basin, eastern Spain. Litho- and biostratigraphy after Moreno-Bedmar et al. (2009). Grey shaded bar corresponds to the OAE 1a interval. 
dominates the assemblages reaching up to $94.5 \%$ (average $84.8 \%$ ), whereas Araucariacites spp. and Inaperturopollenites spp. remain below $4.9 \%$ and $3.8 \%$, respectively. In the subsequent interval (304.3-324.6 m), a relative decline in Classopollis spp. (43.6-72.1\%, average $62.4 \%$ ) is accompanied by a gradual increase in Inaperturopollenites spp. up to $27.0 \%$ (average $12.0 \%$ ) and, less pronounced, in Araucariacites spp. (average $4.5 \%$ ). This is followed by a distinct decrease in the relative proportion of Classopollis (as low as $20.5 \%$ ) in the middle part $(326.5-339.1 \mathrm{~m})$, followed by a gradual increase (up to $78.5 \%$ ) within the upper part of the succession (342.1-401.8 m). Corresponding to the Classopollis minimum at $339.1 \mathrm{~m}$, normalized frequencies of Inaperturopollenites spp. and Araucariacites spp. show an opposing pattern with high abundances (up to $31.6 \%$ and $17.7 \%$, respectively) and display a stepwise decline towards the top of the stratigraphic succession.

\section{Discussion}

\section{6.a. Chemostratigraphic significance}

The overall trend observed in the new composite $\delta^{13} \mathrm{C}$ record for the BdlC section is in good accordance with existing early Aptian carbon isotope curves and enables identification of the characteristic early Aptian chemostratigraphic segments (Menegatti et al. 1998; Millán et al. 2009; Kuhnt, Holbourn \& Moullade, 2011; Hu et al. 2012; Moreno-Bedmar et al. 2012; Gaona-Narvaez, Maurrasse \& Moreno-Bedmar, 2013). However, uncertainties exist with regard to the position of the negative carbon isotope peak (segment C3) and the exact position of the OAE 1a interval. In a previous interpretation of the carbon isotope record, a number of negative $\delta^{13} \mathrm{C}$ values (ranging from -1.4 to $-0.1 \%$ ) have been interpreted to reflect the C3 negative peak located at the base of the OAE 1a (Moreno-Bedmar et al. 2009; Bover-Arnal et al. 2010). These comparatively negative carbon isotope values represent samples taken from an interval composed of an indurated Lithocodium-rich limestone unit (305-311 m), whereas the remainder of the carbon isotope dataset is based on marly lithologies. In order to investigate the isotopic composition and variability of this conspicuous limestone unit, petrographic inspection and geochemical analysis of selected components from the Lithocodium-rich limestone unit has been conducted (Fig. 5). Differentiation between various types of matrices, bioclastic components and cements shows a wide range of $\delta^{13} \mathrm{C}$ signatures with comparatively positive values (up to $+3.4 \%$ ) for biological precipitates (Lithocodium-crust, shell material) to strongly depleted values (as low as $-4.2 \%$ ) for diagenetic cements within a single hand specimen. Analysed bulk limestone samples from this horizon show values between packstone matrix and sparite cement composition, indicating substantial diagenetic alteration of the bulk rock signature. Given the strong heterogeneity of

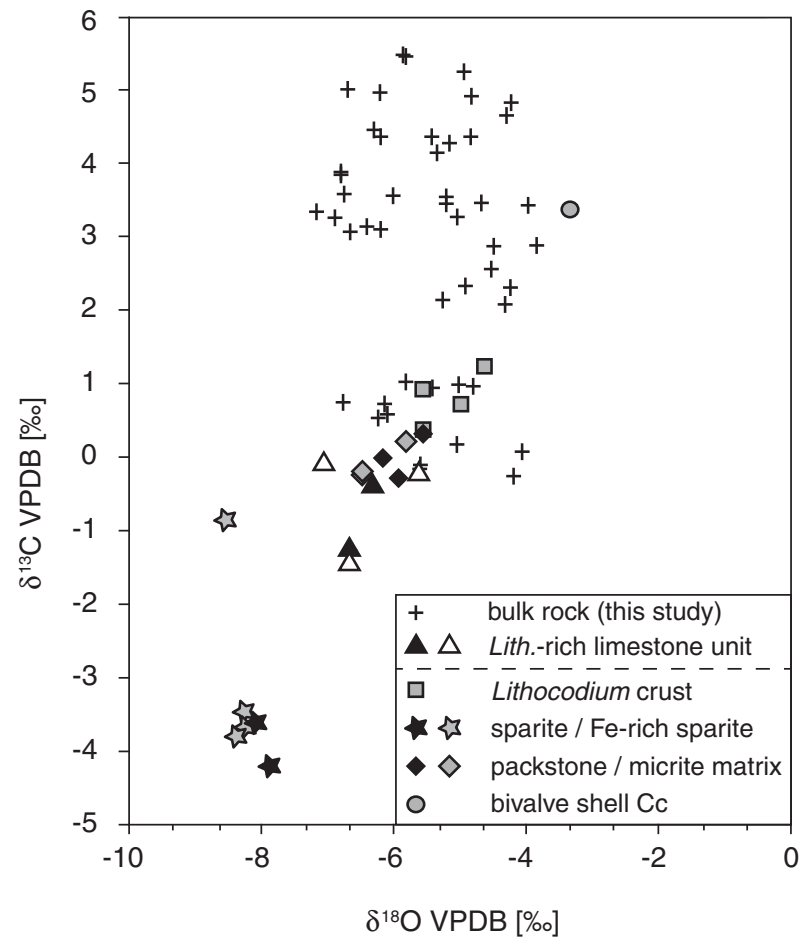

Figure 5. Diagram showing $\delta^{13} \mathrm{C}$ and $\delta^{18} \mathrm{O}$ values from the $\mathrm{BdlC}$ section plotted against each other. Black crosses represent stable isotope data derived from marly lithologies; triangles correspond to bulk rock measurements from the Lithocodium-rich limestone unit in this study (white) and by Bover-Arnal et al. (2010) (black), respectively. Other black and grey symbols correspond to values of different types of carbonate phases from a single hand specimen from the Lithocodium-rich limestone unit.

the Lithocodium-rich limestone unit with regard to its stable isotope signature and the indication for diagenetic alteration of its bulk rock signal, we decide to exclude it from the dataset used for our stratigraphic purposes.

Based on these observations, some modifications in the previous chemostratigraphic interpretation of the BdlC carbon isotope record are proposed. In the revised curve (excluding the negative values from the Lithocodium-rich limestone unit), the $\mathrm{C} 3$ segment is represented by a gradual trend towards minimum values of $-0.3 \%$ spanning the interval between $285 \mathrm{~m}$ and 296 m (Fig. 2). A stratigraphically more extended C3 peak with less negative values is in good accordance with published $\delta^{13} \mathrm{C}$ records from the eastern Iberian Chain (Cap de Vinyet section; Moreno-Bedmar et al. 2009) and the Prebetic domain of Spain (Cau section; Moreno-Bedmar et al. 2012). Furthermore, the revised curve fits well with records from France (La Bedoule section; Moullade et al. 1998; Kuhnt, Holbourn \& Moullade, 2011) and Switzerland (Roter Sattel section; Menegatti et al. 1998) as well as with recently published records from Oman (Vahrenkamp, 2010; Yamamoto et al. 2013) and Tunisia (Heldt, Bachmann \& Lehmann, 2008). As a consequence of the vertical adjustment of the $\mathrm{C} 3$ peak, the subsequent $\mathrm{C} 4$ segment now spans an extended interval between 296 and $312 \mathrm{~m}$. The 
existing chemostratigraphic assignment of the overlying segments $\mathrm{C} 5$ to $\mathrm{C} 8$ is not modified.

The proposed revision of the chemostratigraphic interpretation of the $\mathrm{C} 3$ segment has consequences for the position of the OAE 1a interval in the BdlC section. Based on reference records from Italy and Switzerland (Menegatti et al. 1998; Li et al. 2008), the organic carbon-rich OAE 1a horizon is bracketed by the chemostratigraphic segments C3-C6. By applying the similar stratigraphic subdivision, the OAE $1 \mathrm{a}$ is represented by the interval between $285 \mathrm{~m}$ (base of $\mathrm{C} 3$ ) and $325 \mathrm{~m}$ (top of C6) in the BdlC section. Compared to the previous interpretation, the OAE 1a is now significantly expanded downwards into the lower part of the Forcall Formation spanning a total thickness of $c .40 \mathrm{~m}$. Estimates for the duration of the OAE 1a based on orbital chronologies range between 1.0 and $1.3 \mathrm{Ma}(\mathrm{Li}$ et al. 2008; Malinverno, Erba \& Herbert, 2010) and result in average sedimentation rates of the order 3.1$4.0 \mathrm{~cm} \mathrm{ka}^{-1}$ for the OAE 1a episode in the BdlC section.

\section{6.b. Palynofacies and sea level}

In order to investigate the potential effect of changing depositional environment and/or sea-level fluctuations on the composition of the spore-pollen assemblage, the particulate sedimentary organic matter has been studied as a whole. Qualitative and quantitative analysis of the palynofacies can provide useful information on changing patterns of organic matter sedimentation, and certain parameters can be used to distinguish transgressive-regressive trends in sedimentary successions (Gorin \& Steffen, 1991; Rameil, Götz \& Feist-Burkhardt, 2000; Schiøler, Crampton \& Laird, 2002; Pellaton \& Gorin, 2005). For the Galve sub-basin, two independent and detailed sequencestratigraphic interpretations based on an analysis of facies and depositional environments exist (Vennin \& Aurell, 2001; Bover-Arnal et al. 2010; Embry et al. 2010). These studies agree in interpreting the Forcall and lower Villarroya de los Pinares formations to represent the second of two major transgressive-regressive sequences which characterize early Aptian time. According to these studies, the transgression is marked by the transition from platform carbonates with mud- and wackestone textures towards basinal deposits, including mainly orbitolinid-rich packstones and marls. The establishment of a highstand carbonate platform with rudist bivalves and colonial corals characterizes the regressive stage (Bover-Arnal et al. 2009). The general deepening trend proposed for the Forcall Formation is well displayed in the stratigraphic distribution of the particulate organic matter. Despite certain scatter, the trend visible in the CONT/MAR ratio and the dinoflagellate cyst abundance is in good agreement with the existing sequence-stratigraphic interpretations (Vennin \& Aurell, 2001; Bover-Arnal et al. 2010; Embry et al. 2010). Whereas the lower part of the sequence is characterized by a stepwise decrease in continent-derived organic input, the upper part is marked by the strong dominance of marine dinoflagellate cysts and sparse terrestrial debris (Fig. 2).

The pronounced deepening trend visible in the different fractions of the particulate organic matter has apparently no strong effect on the distribution of the sporomorph assemblage. None of the investigated groups shows a pattern that directly correlates with the CONT/MAR ratio or the dinoflagellate percentage. Even sporomorph types with a documented tendency towards taphonomic enrichment during transport and/or deposition, such as bisaccate pollen or thick-walled ornamented spores (Heusser \& Balsam, 1977; Tyson, 1995; Traverse, 2007), show no distribution pattern that would correspond to the inferred transgressive-regressive trend. Furthermore, the very similar distribution pattern observed in sporomorph groups with very different size and exine thickness (Araucariacites and Inaperturopollenites) is incompatible with strong sorting effects. Hydrodynamic sorting processes associated with sea-level change are therefore considered to be of minor importance in controlling the distribution of spores and pollen in the studied hemipelagic depositional setting. This conclusion is in agreement with the general view that spore-pollen assemblages obtained from open marine settings predominantly reflect changes in vegetation patterns on the adjacent hinterland rather than taphonomic sorting processes during transport and deposition (e.g. Abbink, 1998; van der Kaars, 2001; Moss, Kershaw \& Grindrod, 2005; Traverse, 2007; Schrank, 2010; Dupont, 2011).

\section{6.c. Changes in terrestrial vegetation}

The distribution patterns of the palynoflora show distinct, stepwise changes within the stratigraphic succession (Fig. 4), interpreted to reflect changes in the terrestrial ecosystems of the nearby Iberian Massif and surrounding islands. Before and during the onset of the OAE 1a (upper $\mathrm{C} 2$ and $\mathrm{C} 3$ segments) the vegetation is strongly dominated by drought-resistant (xerophytic) Cheirolepidiaceae, most probably thriving under hot and semi-arid to arid conditions (Doyle, Jardiné \& Doerenkamp, 1982; Vakhrameyev, 1982, 1991; Francis, 1983; Heimhofer et al. 2008; Schrank, 2010; Bonis \& Kürschner, 2012; Riding et al. 2013). A first drop in the abundance of cheirolepideacean conifers during the $\mathrm{C} 4$ interval is paralleled by increasing abundances of Araucariaceae-derived pollen types, which are interpreted to reflect a shift of the forest ecosystem towards warm, mesic habitats with a moderate supply of moisture (Doyle, Jardiné \& Doerenkamp, 1982; Abbink, Van Konijnenburg - Van Cittert \& Visscher, 2004; Schrank, 2010). A similar change from semi-arid to more humid conditions at the onset of the $\mathrm{C} 4$ interval is indicated by a relative increase in kaolinite to the detriment of smectite, mica and chlorite contents. A second, even more pronounced decline in Cheirolepidiaceae begins with the end of segment C6, the horizon, which corresponds to the end of the OAE 1a interval. Cheirolepidiaceans show an abrupt reduction 
here, paralleled by a distinct increase in the relative abundance of Araucariaceae-type conifers. Given the varying ecological requirements of the different conifer types, the observed turnover in the plant ecosystem was most probably driven by a change in climate towards less arid and cooler conditions. A similar shift in the $\mathrm{K} /(\mathrm{M}+\mathrm{C})$ ratio can be interpreted to reflect a change in weathering patterns towards more cooler conditions. Interestingly, trilete spores, which are predominantly produced by leptosporangiate ferns, show no significant changes with stratigraphic height in either terms of frequency abundance or diversity. Given the generally hygrophilous character of many late Mesozoic ferns (e.g. van Konijnenburg - van Cittert, 2002), the stable distribution patterns and low abundances indicate that conditions remained comparatively dry even during the interval characterized by high Araucariaceae abundances. Within segment $\mathrm{C} 7$, the re-establishment of cheirolepidiacean forests is indicated by a successive increase in Classopollis pollen and declining abundances in Araucariacites and Inaperturopollenites. This interpretation is supported by increasing smectite contents paralleled by low kaolinite and decreasing mica contents, indicating a return to more semi-arid climate conditions. However, this latter shift coincides with a distinct increase in dinoflagellate cyst abundance, interpreted to reflect a sea-level rise. Since smectite is usually more abundant in open marine settings, the high smectite ratios may also reflect (at least in partly) a sea-level rise (Adatte, Keller \& Stinnesbeck, 2002).

Comparison with existing terrestrial spore-pollen records from time-equivalent deposits in other Tethyan basins provides further insights into vegetation dynamics during and after OAE 1a (Fig. 6). The strong dominance of thermophilous cheirolepidiacean conifers in the initial phase of the OAE 1a is not restricted to the Maestrat Basin record, but can also be observed at other localities. High Classopollis abundances (36.4-84.9\%) have been reported by Najarro et al. (2011) from the C3 segment of a succession located in the North Cantabrian Basin (Spain). In the study of Keller et al. (2011) based on marine records from the Lombardian and Belluno basins (Italy), the C3 interval (sensu Menegatti et al. 1998) is characterized by a gradual increase in Classopollis with peak values reaching up to $79.3 \%$ within the lower segment $\mathrm{C} 4$. The upper part of $\mathrm{C} 4$ as well as segments $\mathrm{C} 5$ and $\mathrm{C} 6$ are marked by moderately high but fluctuating Classopollis contents, followed by a significant decline subsequent to the termination of the black shale episode (Fig. 6). In the Belluno Basin, the decrease in Cheirolepidiaceaen pollen is paralleled by a dramatic post-OAE rise in bisaccate conifer pollen interpreted to reflect a major cooling episode (Hochuli et al. 1999). High bisaccate abundances are also reported by Najarro et al. (2011) from a single sample attributed to segment C8 (upper Aptian). The spore-pollen distribution patterns observed in the Belluno and Maestrat basins differ markedly from the rather stable Classopollis and Araucariacites pollen contents observed by Heimhofer et al. (2004) in the Vocontian Basin of
SE France. Here, a record covering the upper part of the OAE 1a interval has been studied. The absence of distinct variations in the spore-pollen assemblages led to the conclusion that the OAE 1a itself had no major impact on the vegetation composition surrounding the Vocontian Basin (Heimhofer et al. 2004). However, given the uncertainties in chemostratigraphic correlations across different basins, the Vocontian dataset may actually cover only the C5-C6 segments. Hence, neither the prominent fluctuations in palynoflora at the onset of the OAE 1a (segments C3-C4) nor the major turnover following its termination (C7) seem to be represented in that record.

Regarding the distribution pattern of Classopollis pollen, the records from Italy (Belluno and Lombardian basins) and Spain (Maestrat Basin) show very similar distribution patterns across the OAE 1a interval with high Classopollis contents prevailing within the $\mathrm{C} 3$ and lower C4 segments, followed by a moderate stepwise decline during segments C5-C6. Lowest Classopollis contents are observed in the aftermath of the OAE 1a within segment C7. The main floral turnover is observed at this stratigraphic level, which is characterized by a significant increase in bisaccate conifer pollen in the Belluno Basin (Hochuli et al. 1999) and by a rise in non-saccate pollen types of auraucarian affinity (including Araucariacites, Inaperturopollenites) in the Maestrat Basin. These differences in palynofloral composition are best explained by latitudinal effects due to differing positions of the respective sites within the mid-latitude warm humid belt.

\section{6.d. Terrestrial ecosystem change in response to OAE 1a}

Increased volcanogenic carbon dioxide and other greenhouse gas emissions, in concert with intermittent methane injections from submarine hydrate dissociation, have been proposed to have altered the chemistry of the early Aptian atmosphere and oceans (Jahren et al. 2001; Weissert \& Erba, 2004; Méhay et al. 2009; Erba et al. 2010; Bottini et al. 2012). Excess carbon dioxide levels resulted in exceptional climate warming as indicated by different types of sea-surface temperature (SST) reconstructions (Schouten et al. 2003; Dumitrescu et al. 2006; Ando et al. 2008; Jenkyns et al. 2012).

A phase of warmth at the onset of the OAE 1a is in line with the palynological evidence from the Maestrat and Belluno basins. The high abundances of Classopollis pollen at both sites during the early phase of the event supports a scenario with very warm to hot temperatures triggered by rapid volcanogenic $\mathrm{CO}_{2}$ injection, probably in conjunction with methane hydrate dissociation (Méhay et al. 2009). These unusual climatic conditions may have caused the proliferation of draughtadapted Cheirolepidiacean forests in the studied lower mid-latitude settings. Given the transitional position of the Iberian Massif between two climatic zones, the northwards expansion of the so-called tropicalequatorial hot-arid belt could explain the spread of this 


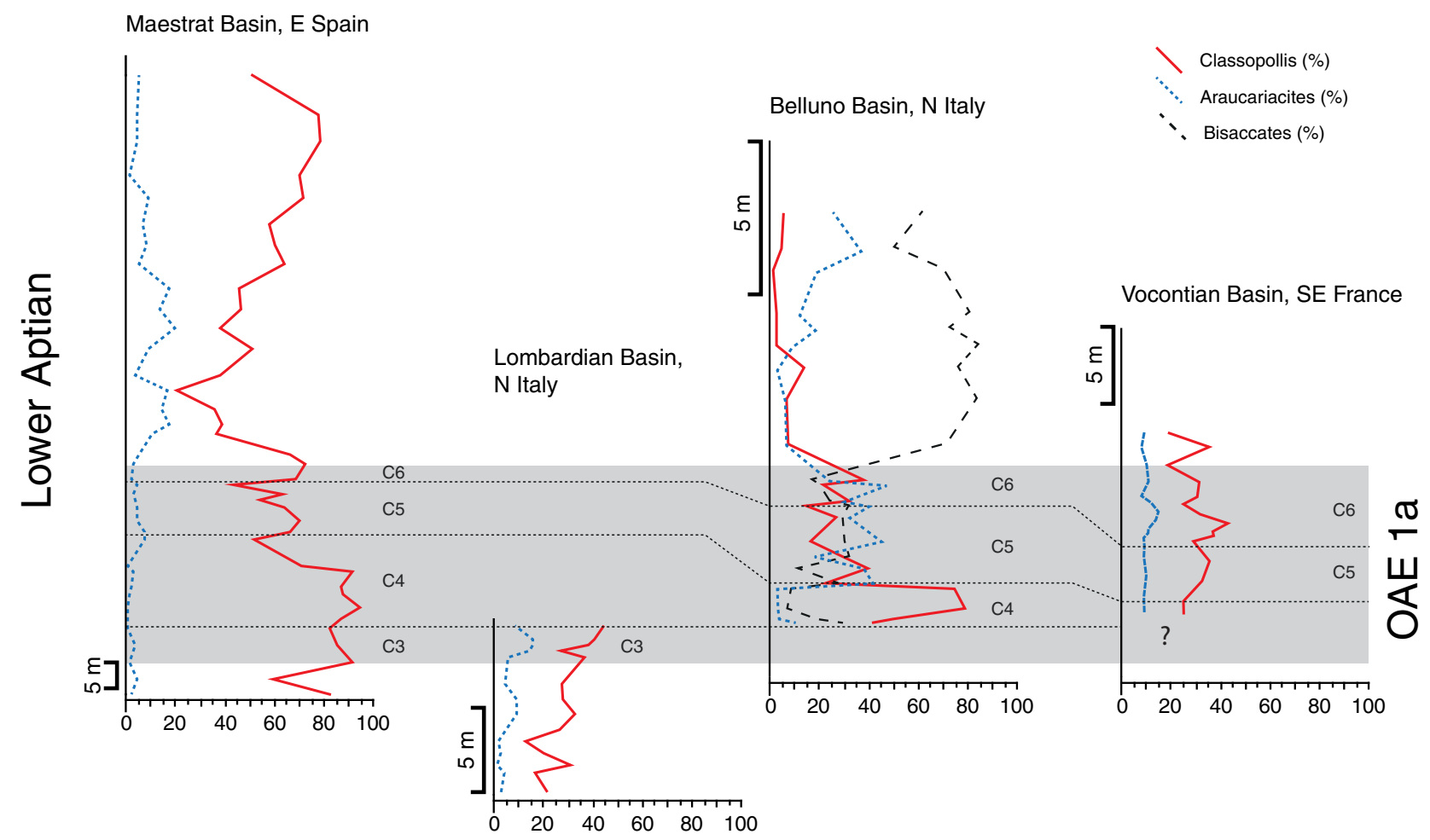

Figure 6. (Colour online) Comparison of relative abundances (\%) of selected gymnosperm pollen types (including Classopollis, Araucariacites and bisaccate pollen) from various Tethyan sites during the early Aptian OAE 1a. Pollen data from the Lombardian Basin are derived from Keller et al. (2011), from the Belluno Basin from Hochuli et al. (1999) and from the Vocontian Basin from Heimhofer et al. (2006).

thermophile plant type during an exceptional hothouse episode at the onset of OAE 1a (Keller et al. 2011).

The initial phase of extraordinary warmth was replaced by a phase of relative climatic cooling, which has been associated with the effect of $\mathrm{CO}_{2}$ drawdown due to enhanced organic carbon burial (Dumitrescu et al. 2006; Ando et al. 2008; Kuhnt, Holbourn \& Moullade, 2011) and/or reduced volcanogenic activity (Keller et al. 2011). Based on $\mathrm{TEX}_{86}$ data from the tropical Pacific, Dumitrescu et al. (2006) reported instabilities in SSTs with two episodes of transient cooling (up to $4{ }^{\circ} \mathrm{C}$ ) during the OAE 1a black shale interval. Similar transient phases of SST decline have been reported from the Cenomanian-Turonian OAE 2 and linked to the effect of excess carbon sequestration (Sinninghe Damste et al. 2010). For the OAE 1a, the intermittent effect of carbon burial (as illustrated in the widespread deposition of organic carbon-rich facies) is considered to have caused short-lasting fluctuations in temperature and humidity in the NW Tethyan realm. This is indicated by the fluctuating, but overall declining abundance trend observed in Cheirolepidiaceans during segments $\mathrm{C} 5$ and $\mathrm{C} 6$ in the Belluno and Maestrat basins.

With the end of segment $\mathrm{C} 6$ (which corresponds to the second positive $\mathrm{C}$-isotope shift), marine black shale deposition ceased worldwide (Menegatti et al. 1998; Bellanca et al. 2002; Price, 2003; Herrle et al. 2004; Robinson et al. 2008; Gaona-Narvaez, Maurrasse \& Moreno-Bedmar, 2013). In contrast, the changes affecting terrestrial ecosystems proceed in the aftermath of the OAE 1a. In the Maestrat Basin, Classopollis pollen reaches its low point (which corresponds to a maximum in Araucaria-derived pollen) about $14.5 \mathrm{~m}$ above the end of segment C6. Similarly, a pronounced decline in Classopollis occurs just above the uppermost organic-rich layer in the Belluno Basin and is paralleled by a major increase in bisaccates (Hochuli et al. 1999). Thus, significant changes in terrestrial vegetation postdate the black shale episode and therefore remain difficult to explain with climatic cooling triggered exclusively by enhanced marine organic carbon accumulation. As noted already by Bralower et al. (1994), the major positive carbon isotope excursion occurs during the late stages of the OAE 1a. In order to explain the temporal lag between marine black shale formation and the subsequent positive carbon isotope shift, burial of organic carbon in marginal marine or continental settings has been suggested as one possibility (Bralower et al. 1994). A similar scenario has recently been proposed to explain the Valanginian positive carbon isotope anomaly, which also lacks time-equivalent marine black shale deposits (Westermann et al. 2010; Kujau et al. 2012;). For the early Aptian period, a change from predominantly marine to terrestrial organic carbon burial would be in line with the existing palynological evidence. Climatic cooling triggered initially by marine black shale formation may have resulted in an equator-wards expansion of the mid- and high-latitude warm and temperate humid belts, thus expanding the area of coal 
formation during Early Cretaceous time (McCabe \& Parrish, 1992). Coals and lignites dated as Aptian have been described from various localities including Artic Canada and the Canadian Rocky Mountains (Bustin \& Smith, 1993; Basset \& Kleinspehn, 1997), NE China (Sha et al. 2008), Mongolia (Erdenetsogt et al. 2009) and SE Russia (Kirillova, 2003). Similarly, the formation and expansion of lacustrine settings often associated with high organic carbon accumulation rates (e.g. Mello and Maxwell, 1990; Ntamak-Nida et al. 2008; Lirong et al. 2013) may have resulted from the expansion of humid zones during early Aptian time. A protracted phase of terrestrial carbon burial in the aftermath of the OAE 1a would also explain the long-lasting interval characterized by positive carbon isotope values during late early Aptian time.

\section{Conclusions}

The normalized frequencies of spore-pollen and clay mineral assemblages derived from the BdlC section, Maestrat Basin, east Spain, show distinct variations with stratigraphic height throughout the early Aptian Forcall Formation, which are paralleled by distinct and well-established changes in the ${ }^{13} \mathrm{C}$ trend before, during and in the aftermath of the OAE 1a interval. Based on comparison with existing interpretations on the evolution of the depositional system and corroborated by new palynofacies data, hydrodynamic sorting due to sea-level changes is not considered as the first-order control on the distribution patterns of the spore-pollen and clay mineral assemblage. The distribution patterns of climate-sensitive conifer pollen support a phase of warmth during the OAE 1a itself. This warm phase is followed by a subsequent cooling, as indicated by significant changes in the gymnosperm pollen assemblage and weathering products. The cooling episode postdates the OAE 1a interval but coincides with a major positive $\delta^{13} \mathrm{C}$ shift, which is interpreted to reflect enhanced $\mathrm{OC}$ burial in the marine realm or on the continents.

Acknowledgements. We thank Ramon Salas (University of Barcelona) and Josep Anton Moreno-Bedmar (UNAM) for their support and help with sampling in the western Maestrat Basin. Christiane Wenske (Leibniz University Hannover) is acknowledged for support with the stable isotope measurements. Financial support from the Nordrhein-Westfälische Akademie der Wissenschaften und Künste to UH and by the $\mathrm{I}+\mathrm{D}+\mathrm{i}$ research project CGL2008-04916 to TBA is gratefully acknowledged.

\section{Declaration of interest}

None

\section{Supplementary material}

To view supplementary material for this article, please visit http://dx.doi.org/10.1017/S0016756814000557

\section{References}

ABBInK, O. A. 1998. Palynological investigations in the Jurassic of the North Sea region. Ph.D. thesis, University of Utrecht, Utrecht, Netherlands. Published thesis.

ABBINK, O. A., VAN KONIJNENBURG - VAN CITTERT, J. H. A. \& VISSCHER, H. 2004. A sporomorph ecogroup model for the Northwest European Jurassic - Lower Cretaceous: concepts and framework. Geologie en Mijnbouw 83, 17-31.

Adatte, T., Keller, G. \& Stinnesbeck, W. 2002. Late Cretaceous to Early Paleogene climate and sea-level fluctuations: the Tunisian record. Palaeogeography, $\mathrm{Pa}$ laeoclimatology, Palaeoecology 178, 165-96.

Ando, A., Kaiho, K., Kawahata, H. \& KaKegawa, T. 2008. Timing and magnitude of early Aptian extreme warming: unraveling primary $\delta^{18} \mathrm{O}$ variation in indurated pelagic carbonates at Deep Sea Drilling Project Site 463, central Pacific Ocean. Palaeogeography, Palaeoclimatology, Palaeoecology 269, 463-76.

BAsset, K. N. \& KLeInSPeHN, K. L. 1997. Early to middle Cretaceous paleogeography of north-central British Columbia: Stratigraphy and basin analysis of the Skeena Group Canadian Journal of Earth Sciences 34, 164469.

Bellanca, A., Erba, E., Neri, R., Premoli, S. I., Sprovieri, M., Tremolada, F. \& Verga, D. 2002. Palaeoceanographic significance of the Tethyan "Livello Selli" (Early Aptian) from the Hybla Formation, northwestern Sicily: biostratigraphy and high-resolution chemostratigraphic records. Palaeogeography, Palaeoclimatology, Palaeoecology 185, 175-96.

BONIS, N. R. \& KÜRSCHNER, W. M. 2012. Vegetation history, diversity patterns, and climate change across the Triassic/Jurassic boundary. Paleobiology 38, 240-64.

Bonis, N. R., KÜRsChner, M. W. \& KRYSTYN, L. 2009. A detailed palynological study of the Triassic-Jurassic transition in key sections of the Eiberg Basin (Northern Calcareous Alps, Austria). Review of Palaeobotany and Palynology 156, 376-400.

Bottini, C., Cohen, A. S., ERBA, E., Jenkyns, H. C. \& CoE, A. L. 2012. Osmium-isotope evidence for volcanism, weathering, and ocean mixing during the early Aptian OAE 1a. Geology 40, 583-6.

Bover-Arnal, T., Moreno-Bedmar, J. A., SAlas, R., SKElTON, P. W., BITZER, K. \& GILI, E. 2010. Sedimentary evolution of an Aptian syn-rift carbonate system (Maestrat Basin, E Spain): effects of accommodation and environmental change. Geologica Acta 8, 249-80.

Bover-Arnal, T., SAlas, R., Martin-Closas, C., SCHLAGINTWEIT, F. \& MORENO-Bedmar, J. A. 2011. Expression of an oceanic anoxic event in a neritic setting: Lower Aptian coral rubble deposits from the Western Maestrat Basin (Iberian Chain, Spain). Palaios 26, 18-32.

Bover-Arnal, T., Salas, R., Moreno-Bedmar, J. A. \& BITZER, K. 2009. Sequence stratigraphy and architecture of a late Early-Middle Aptian carbonate platform succession from the western Maestrat Basin (Iberian Chain, Spain). Sedimentary Geology 219, 280-301.

Bralower, T. J., ARTHUR, M. A., LeCKIE, R. M., SLITER, W. V., Allard, D. J. \& Schlanger, S. O. 1994. Timing and paleoceanography of oceanic dysoxia/anoxia in the Late Barremian to Early Aptian (Early Cretaceous). Palaios 9, 335-69.

Bustin, R. M. \& Smith, G. G. 1993. Coal deposits in the front ranges and foothills of the Canadian Rocky Mountains, southern Canadian Cordillera. International Journal of Coal Geology 23, 1-27. 
Canérot, J., Cugny, P., Pardo, G., SAlas, R. \& Villena, J. 1982. Ibérica central-maestrazgo. In El Cretácico de España (ed. A. García), pp. 273-344. Universidad Complutense de Madrid, Madrid.

Chumakov, N. M., Zharkov, M. A., Herman, A. B., DoludenKo, M. P., Kalandadze, N. M., LebedeV, E. L., Ponomarenko, A. G. \& Rautian, A. S. 1995. Climatic belts of the mid-Cretaceous time. Stratigraphy and Geological Correlation 3, 241-60.

Diéguez, C., Peyrot, D. \& BARRón, E. 2010. Floristic and vegetational changes in the Iberian Peninsula during Jurassic and Cretaceous. Review of Palaeobotany and Palynology 162, 325-40.

DOYLE, J. A., JARDINÉ, S. \& DoERENKAMP, A. 1982. Afropollis, a new genus of early angiosperm pollen, with notes on the Cretaceous palynostratigraphy and palaeoenvironments of northern Gondwana. Bulletin des Centres de Recherches Exploration-Production Elf-Aquitaine 6, 39-117.

Dumitrescu, M., Brassel, S. C., Schouten, S., Hopmans, E. C. \& SinNinghe DAMSTÉ, J. S. 2006. Instability in tropical Pacific sea-surface temperatures during the early Aptian. Geology 34, 833-6.

DuPONT, L. 2011. Orbital scale vegetation change in Africa. Quaternary Science Reviews 30, 3589602.

EMBry, J.-C., Vennin, E., Van Buchem, F. S. P., Schroeder, R., Pierre, C. \& Aurell, M. 2010. Sequence stratigraphy and carbon isotope stratigraphy of an Aptian mixed carbonate-siliciclastic platform to basin transition (Galve sub-basin, NE Spain). In Mesozoic and Cenozoic Carbonate Systems of the Mediterranean and Middle East: Stratigraphic and Diagenetic Reference Models (eds F. S. P. Van Buchem, K. D. Gerdes \& M. Esteban), pp. 113-43. Geological Society of London, Special Publication no. 329.

Erba, E., Bottini, C., Weissert, H. J. \& Keller, C. E. 2010. Calcareous nannoplankton response to surfacewater acidification around Oceanic Anoxic Event 1a. Science 329, 428-32.

Erdenetsogt, B., Lee, I., Bat-Erdene, D. \& Jargal, L. 2009. Mongolian coal-bearing basins: geological settings, coal characteristics, distribution, and resources. International Journal of Coal Geology 80, 87104.

Föllmi, K. B., Godet, A., Bodin, S. \& Linder, P. 2006. Interactions between environmental change and shallow water carbonate buildup along the northern Tethyan margin and their impact on the Early Cretaceous carbon isotope record. Paleoceanography 21, 1-16.

FRANCIS, J. E. 1983. The dominant conifer of the Jurassic Purbeck Formation, England. Palaeontology 26, 277 94.

FriIs, E. M., Pedersen, K. R. \& Crane, P. R. 2010. Cretaceous diversification of angiosperms in the western part of the Iberian Peninsula. Review of Palaeobotany and Palynology 162, 341-61.

GaOna-NarvaEZ, T., MaurRasse, F. J. M. R. \& MorenoBEDMAR, J. A. 2013. Stable carbon-isotope stratigraphy and ammonite biochronology at Madotz, Navarra, northern Spain: implications for the timing and duration of oxygen depletion during OAE-1a. Cretaceous Research 40, 143-57.

Gorin, G. E. \& StefFen, D. 1991. Organic facies as a tool for recording eustatic variations in marine fine-grained carbonates - example of the Berriasian stratotype at Berrias (Ardèche, SE France). Palaeogeography, Palaeoclimatology, Palaeoecology 85, 303-20.
Gradstein, F. M., OGG, J. G., Schmitz, M. \& OGG, G. 2012. The Geologic Time Scale 2012. Oxford, Amsterdam: Elsevier, $1176 \mathrm{pp}$.

Hay, W. W., DeConto, R. M., Wold, C. N., Wilson, K. M., Voigt, S., Schulz, M., Wold, A. R., Dullo, W. C., Ronov, A. B., Balukhovsky, A. N. \& Soeding, E. 1999. Alternative global Cretaceous paleogeography. In Evolution of the Cretaceous Ocean-Climate System (eds E. Barrera \& C. C. Johnson), pp. 1-47. Geological Society of America, Special Paper no. 332.

HAY, W. W. \& Floegel, S. 2012. New thoughts about the Cretaceous climate and oceans. Earth-Science Reviews 115, 262-72.

Heimhofer, U., Adatte, T., Hochuli, P. A., Burla, S. \& WeISSERT, H. 2008. Coastal sediments from the Algarve: low-latitude climate archive for the AptianAlbian. International Journal of Earth Sciences 97, 785-97.

Heimhofer, U., Hochuli, P. A., Herrle, J. O., ANDERSEN, N. \& WEISSERT, H. 2004. Absence of major vegetation and $p \mathrm{CO}_{2}$ changes associated with Oceanic Anoxic Event 1a (Early Aptian, SE France). Earth and Planetary Science Letters 223, 303-18.

Heimhofer, U., Hochuli, P. A., Herrle, J. O. \& Weissert, H. 2006. Contrasting origins of Early Cretaceous black shales in the Vocontian basin: evidence from palynological and calcareous nannofossil records. Palaeogeography, Palaeoclimatology, Palaeoecology 235, 93-109.

HeldT, M., BACHMANN, M. \& LEHMANN, J. 2008. Microfacies, biostratigraphy, and geochemistry of the hemipelagic Barremian-Aptian in north-central Tunisia: influence of the OAE 1 a on the southern Tethys margin. $P a-$ laeogeography, Palaeoclimatology, Palaeoecology 261, 246-60.

Herman, A. B. \& SPICER, R. A. 2010. Mid-Cretaceous floras and climate of the Russian high Arctic (Novosibirsk Islands, Northern Yakutiya). Palaeogeography, Palaeoclimatology, Palaeoecology 295, 409-22.

Hermann, E., Hochuli, P. A., Bucher, H., BrÜHWiler, T., HaUtmanN, M., Ware, D. \& RoOHI, G. 2011. Terrestrial ecosystems on North Gondwana following the end-Permian mass extinction. Gondwana Research 20, 630-7.

Herrle, J. O., KöSsler, P., Friedrich, O., ErlenKeuser, H. \& HeMLEBEN, C. 2004. High-resolution carbon isotope records of the Aptian to Lower Albian from SE France and the Mazagan Plateau (DSPD site 545): a stratigraphic tool for paleocanographic and paleobiologic reconstruction. Earth and Planetary Science Letters 218, 149-61.

Heusser, L. \& BALSAM, W. L. 1977. Pollen distribution in the Northeast Pacific Ocean. Quaternary Research 7, 45-62.

Hochuli, P. A., Menegatti, A. P., Weissert, H., Riva, A., ERBA, E. \& Premoli SiLVA, I. 1999. Episodes of high productivity and cooling in the early Aptian Alpine Tethys. Geology 27, 657-60.

Hochuli, P. A., Os Vigran, J., Hermann, E. \& Bucher, H. 2010. Multiple climatic changes around the PermianTriassic boundary event revealed by an expanded palynological record from mid-Norway. Geological Society of America Bulletin 122, 884-96.

HU, X. M., ZhaO, K. D., YilmaZ, I. O. \& LI, Y. X. 2012. Stratigraphic transition and palaeoenvironmental changes from the Aptian oceanic anoxic event 1a (OAE1a) to the oceanic red bed 1 (ORB1) in the Yenicesihlar section, central Turkey. Cretaceous Research 38, 40-51. 
Huber, B. T., Hodell, D. A. \& Hamilton, C. P. 1995. Middle-Late Cretaceous climate of the southern high latitudes: stable isotopic evidence for minimal equatorto-pole thermal gradients. Geological Society of America Bulletin 107, 1164-91.

Huck, S., Heimhofer, U. \& Immenhauser, A. 2012. Early Aptian algal bloom in a neritic proto-North Atlantic setting: Harbinger of global change related to OAE 1a? Geological Society of America Bulletin 124, 1810-25.

Immenhauser, A., Hillgärtner, H. \& VAN Betum, E. 2005. Microbial-foraminiferal episodes in the Early Aptian of the southern Tethyan margin: ecological significance and possible relation to oceanic anoxic event $1 \mathrm{a}$. Sedimentology 52, 77-99.

Jahren, A. H., Arens, N. C., Sarmiento, G., Guerrero, J. \& AMUNDSON, R. 2001. Terrestrial record of methane hydrate dissociation in the Early Cretaceous. Geology 29, 159-62.

Jaramillo, C., Ochoa, D., Contreras, L., Pagani, M., Carvajal-Ortiz, H., Pratt, L. M., Krishnan, S., CARdona, A., Romero, M., Quiroz, L., Rodriguez, G., Rueda, M. J., De la Parra, F., Moron, S., Green, W., Bayona, G., Montes, C., Quintero, O., RAMirez, R., MORA, G., SCHOUTEN, S., BERMUdEZ, H., Navarrete, R., PARra, F., Alvaran, M., Osorno, J., CRowley, J. L., VAlencia, V. \& VerVOORT, J. 2010. Effects of rapid global warming at the Paleocene-Eocene Boundary on Neotropical Vegetation. Science 330, 95761.

JENKYNS, H. C. 2010. Geochemistry of oceanic anoxic events. Geochemistry, Geophysics, Geosystems 11, doi: 10.1029/2009GC002788.

Jenkyns, H. C., Schouten-Huibers, L., Schouten, S. \& SINNINGHE DAMSTÉ, J. S. 2012. Warm Middle JurassicEarly Cretaceous high-latitude sea-surface temperatures from the Southern Ocean. Climate of the Past 8, 215-26.

Keller, C. E., Hochuli, P. A., Weissert, H., Bernasconi, S. M., Giorgioni, M. \& GARCIA, T. I. 2011. A volcanically induced climate warming and floral change preceded the onset of OAEla (Early Cretaceous). $\mathrm{Pa}$ laeogeography, Palaeoclimatology, Palaeoecology 305, 43-9.

KIDDER, D. L. \& WorsLeY, T. R. 2010. Phanerozoic Large Igneous Provinces (LIPs), HEATT (Haline Euxinic Acidic Thermal Transgression) episodes, and mass extinctions. Palaeogeography, Palaeoclimatology, Palaeoeco$\log y$ 295, 162-91.

KIRILlOVA, G. L. 2003. Late Mesozoic - Cenozoic sedimentary basins of active continental margin of Southeast Russia: paleogeography, tectonics, and coal-oil-gas presence. Marine \& Petroleum Geology 20, 385-97.

KÜBLER, B. 1987. Cristallinite de l'illite, methods normalisees de preparations, methods normalisees de measures. Cahiers de l'Institut de Géologie de Neuchâtel 1.1, 113.

Kuhnt, W., Holbourn, A. \& Moullade, M. 2011. Transient global cooling at the onset of Early Aptian oceanic anoxic event (OAE) 1a. Geology 39, 323-6.

Kujau, A., Heimhofer, U., Ostertag-Henning, C., GRESELle, B. \& MUtTERLOSE, J. 2012. No evidence for anoxia during the Valanginian carbon isotope event: An organic-geochemical study from the Vocontian Basin, SE France. Global and Planetary Change 92-93, 92104.

LARSON, R. L. \& ERBA, E. 1999. Onset of the mid-Cretaceous greenhouse in the Barremian-Aptian igneous events and the biological, sedimentary and geochemical responses. Paleoceanography 14, 663-78.
Li, Y.-X., Bralower, T. J., Montanez, I. P., Osleger, D. A., Arthur, M. A., BiCE, D. M., Herbert, T. D., ERBA, E. \& SilVA, I. P. 2008. Toward an orbital chronology for the early Aptian Oceanic Anoxic Event (OAE1a, $\sim 120$ Ma). Earth and Planetary Science Letters 271, 88-100.

Lirong, D., Dingsheng, C., ZHI, L., ZhiweI, Z. \& JiNGCHUN, W. 2013. Petroleum geology of the fula subbasin, Muglad basin, Sudan. Journal of Petroleum Geo$\log y 36,43-59$.

Looy, C. V., BRugman, W. A., Dilcher, D. L. \& VisScheR, H. 1999. The delayed resurgence of equatorial forests after the Permian-Triassic ecologic crisis. Proceedings of the National Academy of Sciences of the United States of America 96, 13857-62.

Malinverno, A., ERBA, E. \& Herbert, T. D. 2010. Orbital tuning as an inverse problem: chronology of the early Aptian oceanic anoxic event 1a (Selli Level) in the Cismon APTICORE. Paleoceanography 25, 1-16.

MCCABE, P.J. \& PARRISH, J.T. 1992. Tectonic and climatic controls on the distribution and quality of Cretaceous coals. In: Controls on the Distribution and Quality of Cretaceous Coals (eds P.J. McCabe \& J.T. Parrish), pp. 1-15. Geological Society of America, Special Paper no. 267.

McElwain, J. C., BeErling, D. J. \& Woodward, F. I. 1999. Fossil plants and global warming at the Triassic-Jurassic Boundary. Science 285, 1386-90.

Méhay, S., Keller, C. E., Bernasconi, S. M., Weissert, H., Erba, E., Bottini, C. \& Hochuli, P. A. 2009. A volcanic $\mathrm{CO}_{2}$ pulse triggered the Cretaceous Oceanic Anoxic Event 1a and a biocalcification crisis. Geology 37, 819-22.

Mello, M. R. \& MAXWELl, J. R. 1990. Organic geochemical and biological marker characterization of source rocks and oils derived from lacustrine environments in the Brazilian continental margin. In Lacustrine Basin Exploration - Case Studies and Modern Analogs (eds B. J. Katz), pp. 77-97. American Association of Petroleum Geologists, Memoir no. 50.

Menegatti, A. P., Weissert, H., Brown, R. S., Tyson, R. V., FARRIMOND, P., STRASSER, A. \& CARON, M. 1998. Highresolution $\delta^{13} \mathrm{C}$ stratigraphy through the early Aptian "Livello Selli" of the Alpine Tethys. Paleoceanography 13, 530-45.

Millán, M. I., WeisSERT, H. J., FernandeZ-Mendiola, P. A. \& GARCIA-MONDEJAR, J. 2009. Impact of Early Aptian carbon cycle perturbations on evolution of a marine shelf system in the Basque-Cantabrian Basin (Aralar, N Spain). Earth and Planetary Science Letters 287, 392401.

MOORE, D. \& REYNOLDS, R. 1997. X-Ray-Diffraction and the Identification and Analysis of Clay-Minerals. Oxford: Oxford University Press, 378 pp.

Moreno-Bedmar, J. A., Company, M., Bover-Arnal, T., SAlas, R. \& Delanoy, G. 2009. Biostratigraphic characterization by means of ammonoids of the lower Aptian Oceanic Anoxic Event (OAE 1a) in the eastern Iberian Chain (Maestrat Basin, eastern Spain). Cretaceous Research 30, 864-72.

MORENO-BEDMAR, J. A., COMPANY, M., BOVER-ARnAL, T., Salas, R., Delanoy, G., Maurrasse, F. J. M. R., GraugeS, A. \& MARTINEZ, R. 2010. Lower Aptian ammonite biostratigraphy in the Maestrat Basin (Eastern Iberian Chain, Eastern Spain). A Tethyan transgressive record enhanced by synrift subsidence. Geologica Acta 8, 281-99.

Moreno-Bedmar, J. A., COMPANY, M., SANDOVAL, J., TAVERA, J. M., Bover-ARnAL, T., SAlas, R., 
Delanoy, G., Maurrasse, F. J. M. R. \& Martinez, R. 2012. Lower Aptian ammonite and carbon isotope stratigraphy in the eastern Prebetic Domain (Betic Cordillera, southeastern Spain). Geologica Acta 10, 333-50.

Moss, P. T., KershaW, A. P. \& Grindrod, J. 2005. Pollen transport and deposition in riverine and marine environments within the humid tropics of northeastern Australia. Review of Palaeobotany and Palynology 134, 5569.

Moullade, M., Kuhnt, W., Bergen, J. A., Masse, J. P. \& TRONCHETTI, G. 1998. Correlation of biostratigraphic and stable isotope events in the Aptian historical stratotype of La Bedoule (southeast France). Comptes Rendus de l'Académie des Sciences - Serie II A - Earth and Planetary Science 327, 693-8.

NAJARro, M., Rosales, I., Moreno-Bedmar, J. A., DE GEA, G. A., BARRON, E., COMPANY, M. \& DELANOY, G. 2011. High-resolution chemo- and biostratigraphic records of the Early Aptian oceanic anoxic event in Cantabria (N Spain): Palaeoceanographic and palaeoclimatic implications. Palaeogeography, Palaeoclimatology, Palaeoecology 299, 137-58.

NTAMAK-NIDA, M.-J., BAUdIN, F., SCHNYDER, J., MAKONG, J.-C., Komguem, P. B. \& Abolo, G. M. 2008. Depositional environments and characterisation of the organic matter of the Lower Mundeck Formation (Barremian ?-Aptian) of the Kribi-Campo sub-basin (South Cameroon): Implications for petroleum exploration. Journal of African Earth Sciences 51, 207-19.

Pancost, R. D., Crawford, N., Magness, S., Turner, A., JENKYNS, H. C. \& MAXWELL, J. R. 2004. Further evidence for the development of photic-zone euxinic conditions during Mesozoic oceanic anoxic events. Journal of the Geological Society, London 161, 353-64.

Pellaton, C. \& Gorin, G. E. 2005. The Miocene New Jersey passive margin as a model for the distribution of sedimentary organic matter in siliciclastic deposits. Journal of Sedimentary Research 75, 1011-27.

PRICE, G. D. 1999. The evidence and implications of polar ice during the Mesozoic. Earth-Science Reviews 48, 183 210.

PRICE, G. D. 2003. New constraints upon isotope variation during the early Cretaceous (Barremian-Cenomanian) from the Pacific Ocean. Geological Magazine 140, 51322.

Quijano, L. M., Manuel Castro, J., Pancost, R. D., DE Gea, G. A., Najarro, M., Aguado, R., Rosales, I. \& MARTIN-ChIVElET, J. 2012. Organic geochemistry, stable isotopes, and facies analysis of the Early Aptian OAE - New records from Spain (Western Tethys). $P a$ laeogeography, Palaeoclimatology, Palaeoecology 365, 276-93.

Rameil, N., Götz, A. E. \& Feist-Burkhardt, S. 2000. High-resolution sequence interpretation of epeiric shelf carbonates by means of palynofacies analysis: An example from the Germanic Triassic (Lower Muschelkalk, Anisian) of East Thuringia, Germany. Facies 43, 12343.

Riding, J. B., Leng, M. J., Kender, S., Hesselbo, S. P. \& FEIST-BURKHARDT, S. 2013. Isotopic and palynological evidence for a new Early Jurassic environmental perturbation. Palaeogeography, Palaeoclimatology, $\mathrm{Pa}$ laeoecology 374, 16-27.

Robinson, S. A., Clarke, L. J., Nederbragt, A. \& Wood, I. G. 2008. Mid-Cretaceous oceanic anoxic events in the Pacific Ocean revealed by carbon-isotope stratigraphy of the Calera Limestone, California, USA. Geological Society of America Bulletin 120, 1416-27.
Ruffell, A. H. \& BATTEN, D. J. 1990. The Barremian-Aptian arid phase in western Europe. Palaeogeography, Palaeoclimatology, Palaeoecology 80, 197-212.

SAlas, R., Guimera, J., Mas, R., Martin-Closas, C., Melendez, A. \& Alonso, A. 2001. Evolution of the Mesozoic Central Iberian Rift System and its Cenozoic inversion (Iberian chain). In Peri-Tethys Memoir 6: Peri-Tethyan Rift/Wrench Basins and Passive Margins (eds P. A. Ziegler, W. Cavazza, A. H. F. Robertson \& S. CrasquinSoleau), pp. 145-86. Memoires du Museum National d'Histoire Naturelle, Paris, 186.

SAlas, R., Martín-Closas, C., Delclòs, X., Guimerà, J., CAJA, M. A. \& MAS, R. 2005. Factores principales de control de la sedimentación y los cambios bióticos durante el tránsito Jurásico-Cretácico en la Cadena Ibérica. Geogaceta 38, 15-8.

SCHIØLER, P., CRAMPTON, J. S. \& LAIRD, M. G. 2002. Palynofacies and sea-level changes in the Middle ConiacianLate Campanian (Late Cretaceous) of the East Coast Basin, New Zealand. Palaeogeography, Palaeoclimatology, Palaeoecology 188, 101-25.

Schouten, S., Hopmans, E. C., Forster, A., van Breugel, Y., KUYPERS, M. M. M. \& Sinninghe DAMSTÉ, J. S. 2003. Extremely high sea-surface temperatures at low latitudes during the middle Cretaceous as revealed by archaeal membrane lipids. Geology 31, 1069-72.

SCHRANK, E. 2010. Pollen and spores from the Tendaguru Beds, Upper Jurassic and Lower Cretaceous of southeast Tanzania: palynostratigraphical and paleoecological implications. Palynology 34, 3-42.

SEWALl, J. O., van DE WAL, R. S. W., VAN DER ZWAN, K., van Oosterhout, C., Dijkstra, H. A. \& Scotese, C. R. 2007. Climate model boundary conditions for four Cretaceous time slices. Climate of the Past 3, 647-57.

SHA, J., HIROMICHI, H., YAO, X. \& PAN, Y. 2008. Late Mesozoic transgressions of eastern Heilongjiang and their significance in tectonics, and coal and oil accumulation in northeast China. Palaeogeography, Palaeoclimatology, Palaeoecology 263, 119-30.

Sinninghe Damste, J. S., van Bentum, E. C., Reichart, G. J., Pross, J. \& Schouten, S. 2010. A CO 2 decreasedriven cooling and increased latitudinal temperature gradient during the mid-Cretaceous Oceanic Anoxic Event 2. Earth and Planetary Science Letters 293, 97103.

Skelton, P. W., Spicer, R. A., Kelley, S. P. \& Gilmour, I. 2003. The Cretaceous World. Cambridge: Cambridge University Press, $360 \mathrm{pp}$.

Solé de Porta, N., Querol, X., CABanes, R. \& SAlas, R. 1994. Nuevas aportaciones a la palinología y paleoclimatología de la Formación Esucha (Albiense inferiormedio) en las Cubetas de Utrillas y Oliete, Cordillera Ibérica Oriental. Cuadernos Geología Ibérica 18, 203 15.

STAPLIN, F. L. 1982. Determination of thermal alteration index from color of exinite (pollen, spores). In How to Assess Maturation and Paleotemperatures (ed. F. L. Staplin), pp. 7-11. Society of Economic Paleontologists and Mineralogists, Short Course no. 7.

Steffen, D. \& GoRIN, G. 1993. Palynofacies of the Upper Tithonian - Berriasian deep-sea carbonates in the Vocontian Trough (SE France). Bulletin Des Centres De Recherches Exploration-Production Elf Aquitaine 17, 235-47.

TraVerse, A. 2007. Paleopalynology. Dordrecht: Springer, $813 \mathrm{pp}$.

TYSON, R. V. 1995. Sedimentary Organic Matter. London: Chapman \& Hall, 615 pp. 
VAHRENKAMP, V. C. 2010. Chemostratigraphy of the Lower Cretaceous Shu'aiba Formation: A d13C reference profile for the Aptian Stage from the Southern Neo-Tehtys Ocean. In Barremian-Aptian Stratigraphy and Hydrocarbon Habitat of the Eastern Arabian Plate (eds F. S. P. Van Buchem, M. I. Al-Husseini, F. Maurer \& H. Droste), pp. 107-37. GeoArabia Special Publication no. 4.

VAKHRAMEYEV, V. A. 1982. Classopollis pollen as an indicator of Jurassic and Cretaceous climate. International Geology Review 24, 1190-6.

VAKHRAMEYEV, V. A. 1991. Jurassic and Cretaceous Floras and Climates of the Earth. Cambridge: Cambridge University Press, $318 \mathrm{pp}$.

VAN DE SchootbrugGe, B., QuAn, T. M., Lindstrom, S., Puettmann, W., Heunisch, C., Pross, J., Fiebig, J., Petschick, R., Roehling, H. G., Richoz, S., Rosenthal, Y. \& Falkowski, P. G. 2009. Floral changes across the Triassic/Jurassic boundary linked to flood basalt volcanism. Nature Geoscience 2, 589-94.

VAN DER KAARS, S. 2001. Pollen distribution in marine sediments from the south-eastern Indonesian waters. $\mathrm{Pa}$ laeogeography, Palaeoclimatology, Palaeoecology 171, 341-61.

VAN KONIJNENBURG - VAN CITTERT, J. 2002. Ecology of some Late Triassic to Early Cretaceous ferns in Eurasia. Review of Palaeobotany and Palynology 119, 113-24.

VENNIN, E. \& AURELL, M. 2001. Aptian paleoenvironmental evolution and sequence stratigraphy in the Galve sub- basin (Teruel, NE Spain). Bulletin de la Societe Geologique de France 172, 397-410.

WeISSERT, H. \& ERBA, E. 2004. Volcanism, $\mathrm{CO}_{2}$ and palaeoclimate: a Late Jurassic-Early Cretaceous carbon and oxygen isotope record. Journal of the Geological Society, London 161, 695-702.

Westermann, S., Föllmi, K. B., Adatte, T., Matera, V., Schnyder, J., Fleitmann, D., Fiet, N., Ploch, I. \& Duchamp-Alphonse, S. 2010. The Valanginian $\delta^{13} \mathrm{C}$ excursion may not be an expression of a global anoxic event. Earth and Planetary Science Letters 290, 118-31.

Wing, S. L., HARrington, G. J., SMith, F. A., BlOCH, J. I., BoYer, D. M. \& FrEEMAN, K. H. 2005. Transient floral change and rapid global warming at the PaleoceneEocene boundary. Science 310, 993-6.

WiSSLER, L., FUnK, H. \& WEISSERT, H. 2003. Response of Early Cretaceous carbonate platforms to changes in atmospheric carbon dioxide levels. Palaeogeography, $\mathrm{Pa}$ laeoclimatology, Palaeoecology 200, 187-205.

YAMAMOTO, K., ISHIBASHI, M., TAKAYANAGI, H., ASAHARA, Y., SATO, T., Nishi, H. \& IRYU, Y. 2013. Early Aptian paleoenvironmental evolution of the Bab Basin at the southern Neo-Tethys margin: response to global carbon-cycle perturbations across Ocean Anoxic Event 1a. Geochemistry, Geophysics, Geosystems 14, doi: 10.1002/ggge.20083.

ZIEGLeR, A. M. 1990. Geological Atlas of Western and Central Europe. London: Geological Society Publishing House, 239 pp. 